\title{
Chitosan Activated with Genipin: A Nontoxic Natural Carrier for Tannase Immobilization and Its Application in Enhancing Biological Activities of Tea Extract
}

\author{
Chi Wang ${ }^{1,+}{ }^{+}$Pei-Xu Chen ${ }^{1,+}$, Qiong Xiao ${ }^{1,2,3}$, Qiu-Ming Yang ${ }^{1,2,3}$, Hui-Fen Weng ${ }^{1,2,3}$, Yong-Hui Zhang ${ }^{1,2,3, *}$ (1) \\ and An-Feng Xiao ${ }^{1,2,3, *}$ \\ 1 College of Food and Biological Engineering, Jimei University, Xiamen 361021, China; \\ wangmou007@jmu.edu.cn (C.W.); chenxuxu1205@jmu.edu.cn (P.-X.C.); xiaoqiong129@jmu.edu.cn (Q.X.); \\ yangqm@jmu.edu.cn (Q.-M.Y.); wenghuifen@jmu.edu.cn (H.-F.W.) \\ 2 Fujian Provincial Engineering Technology Research Center of Marine Functional Food, Xiamen 361021, China \\ 3 Xiamen Key Laboratory of Marine Functional Food, Xiamen 361021, China \\ * Correspondence: yhz@jmu.edu.cn (Y.-H.Z.); xxaaffeng@jmu.edu.cn (A.-F.X.); \\ Tel.: +86-592-6181487 (Y.-H.Z.); +86-592-6180075 (A.-F.X.) \\ + These authors contributed equally to this paper.
}

\section{check for} updates

Citation: Wang, C.; Chen, P.-X.; Xiao, Q.; Yang, Q.-M.; Weng, H.-F.; Zhang, Y.-H.; Xiao, A.-F. Chitosan Activated with Genipin: A Nontoxic Natural Carrier for Tannase Immobilization and Its Application in Enhancing Biological Activities of Tea Extract. Mar. Drugs 2021, 19, 166. https:// doi.org/10.3390/md19030166

Academic Editor: Jessica

Amber Jennings

Received: 27 February 2021

Accepted: 17 March 2021

Published: 19 March 2021

Publisher's Note: MDPI stays neutral with regard to jurisdictional claims in published maps and institutional affiliations.

Copyright: (c) 2021 by the authors. Licensee MDPI, Basel, Switzerland. This article is an open access article distributed under the terms and conditions of the Creative Commons Attribution (CC BY) license (https:/ / creativecommons.org/licenses/by/ $4.0 /)$.

\begin{abstract}
In this work, a non-toxic chitosan-based carrier was constructed via genipin activation and applied for the immobilization of tannase. The immobilization carriers and immobilized tannase were characterized using Fourier transform infrared spectroscopy and thermogravimetric analysis. Activation conditions (genipin concentration, activation temperature, activation $\mathrm{pH}$ and activation time) and immobilizations conditions (enzyme amount, immobilization time, immobilization temperature, immobilization $\mathrm{pH}$, and shaking speed) were optimized. The activity and activity recovery rate of the immobilized tannase prepared using optimal activation and immobilization conditions reached $29.2 \mathrm{U} / \mathrm{g}$ and $53.6 \%$, respectively. The immobilized tannase exhibited better environmental adaptability and stability. The immobilized tannase retained $20.1 \%$ of the initial activity after 12 cycles and retained $81.12 \%$ of residual activity after 30 days storage. The catechins composition analysis of tea extract indicated that the concentration of non-ester-type catechins, EGC and EC, were increased by $1758 \%$ and $807 \%$ after enzymatic treatment. Biological activity studies of tea extract revealed that tea extract treated with the immobilized tannase possessed higher antioxidant activity, higher inhibitory effect on $\alpha$-amylase, and lower inhibitory effect on $\alpha$-glucosidase. Our results demonstrate that chitosan activated with genipin could be an effective non-toxic carrier for tannase immobilization and enhancing biological activities of tea extract.
\end{abstract}

Keywords: chitosan; genipin; tannase; tea extract; antioxidant activity; $\alpha$-amylase; $\alpha$-glucosidase

\section{Introduction}

Green tea extracts, which constitutes approximately $30 \%$ of the weight of the tea leaves, play a key role because they are rich in polyphenols and have various biological activities [1,2]. The predominant forms of tea polyphenols include catechins and other flavanol derivatives [3], such as epigallocatechin gallate (EGCG), epigallocatechin (EGC), epicatechin gallate (ECG), and epicatechin (EC). Despite their excellent biological activities, catechins are major contributors to the astringent and bitter taste of green tea infusions [4]. In addition, polyphenol complexation is the main driver of tea paste formation and influenced by the quantities of galloyl and hydroxyl groups in polyphenols [5].

Tannase (Tannase, EC 3.1.1.20) is a hydrolase mainly derived from microorganism such as Aspergillus [6,7], Penicillium [8,9], and Kluyveromyces [10]. The ester bonds and carboxyphenolic acid bonds in polyphenol substances can be hydrolyzed by tannase to produce gallic acid and corresponding alcohols. Tannase was utilized to cleave the ester bonds of certain tannins in tea infusion and thereby prevented the complex formation of 
tannins with caffeine and increased the stability of tea infusion [11]. Ester-type catechins (EGCG and ECG) [12] in tea infusion could be hydrolyzed into non-ester-type catechins (EGC and EC), which improved the sweet aftertaste of tea infusion since EGC and EC are the main contributors for sweet aftertaste. Tannase treatment was also shown to increase polyphenol recovery rate $[13,14]$ in tea extraction process due to the degradation due to its hydrolysis toward the diferulic acid dimer in the plant cell wall. The biological activities of tannase-treated tea extracts, such as antioxidant activity and inhibition effect on digestive enzymes, are also improved [15].

Despite the advantages of the enzymatic treatment of tea extracts, particularly high catalytic efficiency, mild reaction conditions, and low degree of contamination, it has the disadvantages of insufficient stability and inability to recycle, which make the process costly and difficult to implement $[16,17]$. Enzyme immobilization is a suitable approach to resolve this application problem. Enzyme immobilization normally utilized solid materials to restrain enzymes to a certain space for catalytic reaction, which can be recycled to reduce catalyst cost [18]. Immobilizing enzymes with proper immobilization strategy can greatly improve enzymatic properties and catalytic performance, including activity, stability, adaptability, specificity, selectivity, reduce inhibitions, etc. [19-21]. Many approaches for tannase immobilization have been proposed, for example, the use of carboxyl-functionalized $\mathrm{Fe}_{3} \mathrm{O}_{4}$ nanoparticles [22], chitin-alginate composites [23], and chitosan [24-26].

Chitosan an N-deacetylated derivative of chitin, mainly extracted from shells of marine crustaceans (crabs, shrimps, lobsters, etc.). Chitosan has unique chemical and biological properties. In its linear polyglucosamine chains of high molecular weight, chitosan has active amino and hydroxyl groups for easy chemical modification $[27,28]$. Moreover, the existence of amino groups makes chitosan a cationic polyelectrolyte $(\mathrm{pKa} \approx 6.5)$. Thus, chitosan's high solubility in acidic solutions and its aggregation with polyanions give it excellent glue-forming properties [29]. Owing to its nontoxicity, biodegradability properties, and biocompatibility, it has been widely used as an excellent natural material in industrial and biomedical applications, such as for protein delivery [30], drug delivery [31], as a gene carrier [32], and for enzyme immobilization [33-35]. As in the above applications, the various forms that chitosan polymers take, such as beads/microspheres, microcapsules, fibers, membranes, coatings, sponges, and gels with different geometrical configurations, expand their use as carriers to support a large number of biomolecules or industrially relevant enzymes [36]. Despite the promising application of various forms of chitosan polymers as carriers for immobilized enzymes, they have relatively weak properties and poor mechanical stability $[37,38]$. Enzymes could be immobilized by chitosan via simple adsorption, mainly through weak forces between the substrate and the enzyme, such as electrostatic or hydrophobic interactions. However, this may lead to enzyme leakage during recycle. Glutaraldehyde was utilized as a versatile activation reagent or crosslinking reagent for enhancing the immobilization efficiency of chitosan. However, from a safety point of view, glutaraldehyde was shown to be corrosive, irritating, toxic to humans, and hazardous to aquatic organisms [39]. For these reasons, the use of safer cross-linking agents to effectively immobilize enzymes remains an ongoing challenge.

Genipin is a natural chemical compound that can be extracted from gardenia fruit $[40,41]$. A genipin molecule contains a glutaraldehyde group, which facilitates the cross-linking of genipin with proteins, collagen, gelatin, and chitosan. As a novel cross-linking reagent for substituting glutaraldehyde, genipin has the advantages of natural source, high crosslinking efficiency, and low cytotoxicity (approximately 1/10,000 [42] that of glutaraldehyde). To date, genipin has been used in the immobilizing keratinase [43], $\beta$-galactosidase [24,26], and lipase [44]. However, to the best of our knowledge, immobilizing tannase on genipin cross-linked chitosan (GP-CS) carriers and the effect of tannase immobilized on GP-CS (GP-CS-tannase) on the biological activities of tea extracts have not been explored.

In this study, we selected tannase from Aspergillus oryzae FJ0123 as a model to explore the potential use of GP-CS in enzyme immobilization and enhancing the biological activities of tea extracts. The effect of genipin activation conditions and immobilization 
conditions, such as genipin concentration, enzyme concentration, $\mathrm{pH}$, temperature, and reaction time, were investigated in detail. Catechins composition and the biological activities of tea extracts prepared with GP-CS-tannase were determined, and the reusability of GP-CS-tannase was examined.

\section{Results and Discussion}

\subsection{Determination of the Working Activation Conditions for Chitosan Beads}

A preliminary research was carried out to compare the effects of glutaraldehyde and genipin on the effect of chitosan immobilized enzyme. The results were listed in the supporting material. As shown in Figure S1, although the recovery rate of GP-CS-tannase was 3.2\% lower than that activated with glutaraldehyde, genipin still exhibited a competitive efficiency for tannase immobilization compared with glutaraldehyde. Therefore, it is worth to investigate genipin immobilization of tannase for non-toxic and safe subsequent production of tea extracts.

The effect of activation conditions on the recovery of tannase activity after immobilization with GP-CS was examined. As can be seen in Figure 1a, the recovery of enzyme activity at this time reached $7.4 \%$ when the concentration of genipin in the system was 0 . The activity was due to the physical adsorption and ion exchange [45-47] of chitosan on tannase, which was not easily eluted by the buffer. Enzyme activity recovery and specific enzyme activity were $19.2 \%$ and $10.0 \mathrm{U} / \mathrm{g}$, respectively, when the amount of genipin was increased to $0.4 \mathrm{mg} / \mathrm{mL}$. Continuous increase in the amount of genipin resulted in a decrease in enzyme activity because of genipin saturation and production of internal polymerization of genipin-genipin and genipin-chitosan, resulting in a decrease in the effective groups bound to the enzyme $[43,48]$.
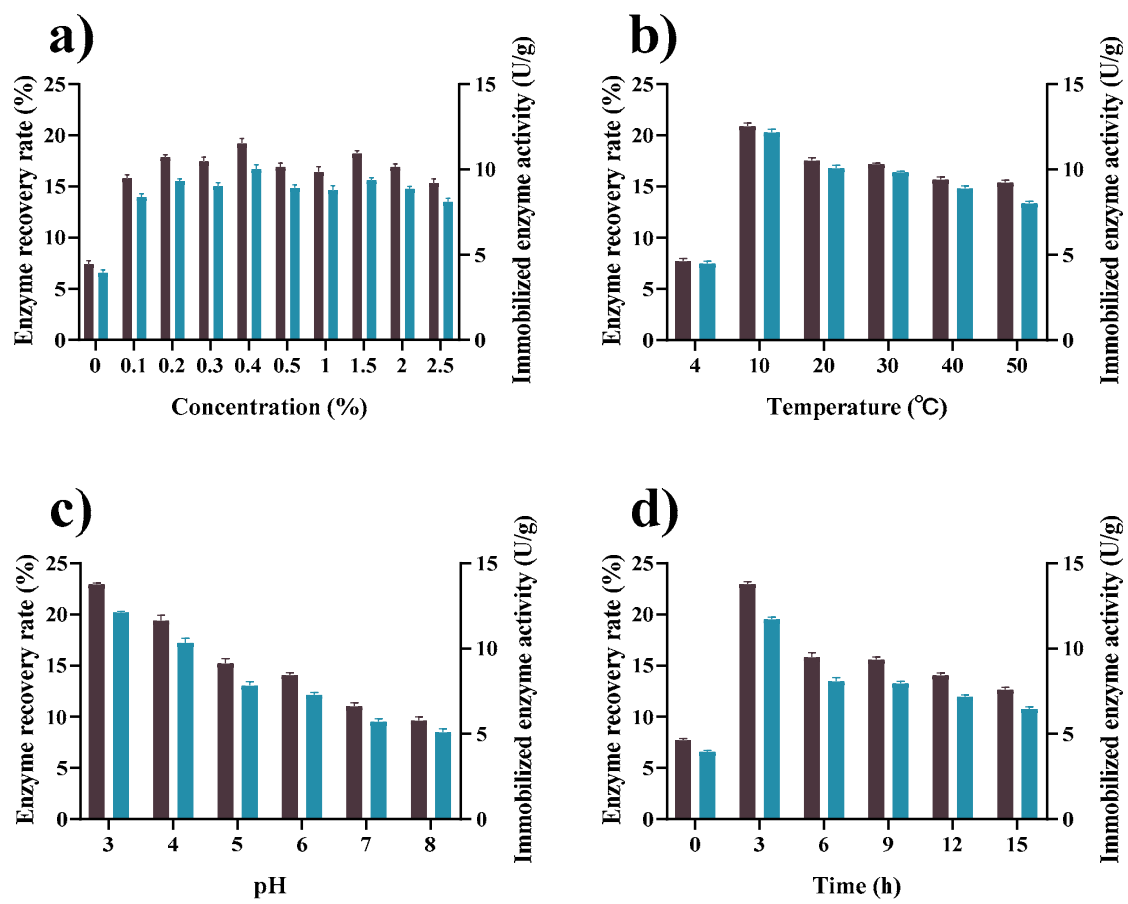

Figure 1. Effect of activation conditions: (a) genipin concentration $(0-2.5 \%, m / v)$, (b) activation temperature $\left(4-50^{\circ} \mathrm{C}\right),(\mathrm{c})$ activation $\mathrm{pH}$ (citrate buffer at $\mathrm{pH} 3.0-6.0$, and phosphate at $\mathrm{pH}$ 6.0-8.0), and (d) activation time (0-15 h) on the enzyme recovery rate ( $\square)$ of immobilized tannase and enzyme activity ( $\square$ ); other immobilization conditions were carried out as in Section 3.2. After the activation step, excess genipin was washed off with $200 \mathrm{~mL}$ of deionized (DI) water, and GP-CS was used for immobilization. The activity of immobilized enzyme was determined under standard conditions $\left(30^{\circ} \mathrm{C}\right.$, citrate buffer at $\mathrm{pH}$ 5.0). All data represent the mean \pm standard deviation of triplicate measurements. 
The effect of activation temperature on the enzyme recovery rate was studied. The result is shown in Figure $1 \mathrm{~b}$. The optimal temperature for chitosan activation was $10^{\circ} \mathrm{C}$, at which the highest immobilization efficiency (20.9\%) was obtained. The result indicated that the activating reaction between genipin and chitosan exerted better at lower temperatures. When the activation temperature was raised to $50{ }^{\circ} \mathrm{C}$, the recovery rate of tannase activity was only $15.4 \%$, which was $75 \%$ of that at $10{ }^{\circ} \mathrm{C}$.

The cross-linking reaction between chitosan and genipin had different reaction mechanisms at varied $\mathrm{pH}$, which greatly influence the carrier activation process [49]. Under acidic and neutral conditions, the amino group of chitosan executes a nucleophilic attack on the alkene carbon atom at C-3, which then opens the dihydropyran ring, and the secondary amino group attacks the newly formed aldehyde group. In other words, genipin acts as a double aldehyde, but its condensation product is much more stable than glutaraldehyde. In the product, the shortchain of a condensed genipin acts as a cross-linking aldehyde. Under alkaline conditions, the ring-opening reaction of genipin results in the formation of intermediate aldehyde groups by facilitating the nucleophilic attack of hydroxyl groups in aqueous solutions, which then undergo aldol condensation reactions. The terminal aldehyde group on polymerized genipin undergoes a Schiff reaction with the chitosan amino group and forms a cross-linked network [49-52]. As shown in Figure 1c, the recovery rate of tannase activity reached $22.9 \%$ at $\mathrm{pH} 3$, and the recovery rate decreased with increasing activation $\mathrm{pH}$. When $\mathrm{pH}$ was adjusted to 8 , the recovery rate of tannase activity was only $41.9 \%$ of that at $\mathrm{pH}$. The high proton environment at a low $\mathrm{pH}$ provides suitable conditions for nucleophilic attack of primary amines on the C3 of genipin. Subsequently, the Schiff base reaction between the formed genipin aldehyde group and the enzyme protein occurs [53].

Figure $1 \mathrm{~d}$ shows the effect of activation time on the immobilization process. When the activation time reached $3 \mathrm{~h}$, the enzyme recovery rate and enzyme activity peaked at $22.9 \%$ and $11.7 \mathrm{U} / \mathrm{g}$, respectively. Enzyme recovery rate and enzyme activity slowly decreased with increasing the activation time. An increase in activation time may intensify the internal polymerization of genipin-genipin, leading to a decrease in the effective ligation capacity of chitosan for tannase [54].

\subsection{FTIR Analysis}

Figure 2 shows the FTIR spectra of CS, GP-CS, and GP-CS-tannase. The CS spectrum showed absorption peaks at 1656 and $1600 \mathrm{~cm}^{-1}$ [24], which indicated the N-H bending vibrations of the primary amine on the chitosan structure. Additionally, the symmetrical angular deformation peak characteristic of $\mathrm{CH} 3$ at $1381 \mathrm{~cm}^{-1}$ was observed [55]. The absorption spectrum from $1000 \mathrm{~cm}^{-1}$ and $1100 \mathrm{~cm}^{-1}$ was dominated by C-O and C-N stretching vibrations and C-C-N bending vibrations [56]. After cross-linking with genipin, amide II on GP-CS showed N-H deformation at $1580 \mathrm{~cm}^{-1}$. The deformation may have resulted from the reaction of genipin ester with hydroxyl and chitosan amino groups and produced secondary amides [56]. The peak at $1656 \mathrm{~cm}^{-1}$ was attributed to $\mathrm{C}=\mathrm{O}$ stretching in the secondary amide. The spectrum of GP-CS-tannase has an amide band $\left(1656 \mathrm{~cm}^{-1}\right.$, $1580 \mathrm{~cm}^{-1}$ ) similar to that of GP-CS, since the mechanism involved in the cross-linking reaction in the presence of the enzyme was the same as that involved in the cross-linking reaction of chitosan particles (CS). The increase in characteristic band intensity may be due to an increase in available amino groups (from adsorption enzymes), which react with genipin, which promoted an increase in cross-linking groups, such as amide bonds [24]. These results indicated that the genipin groups attached to chitosan particles. 


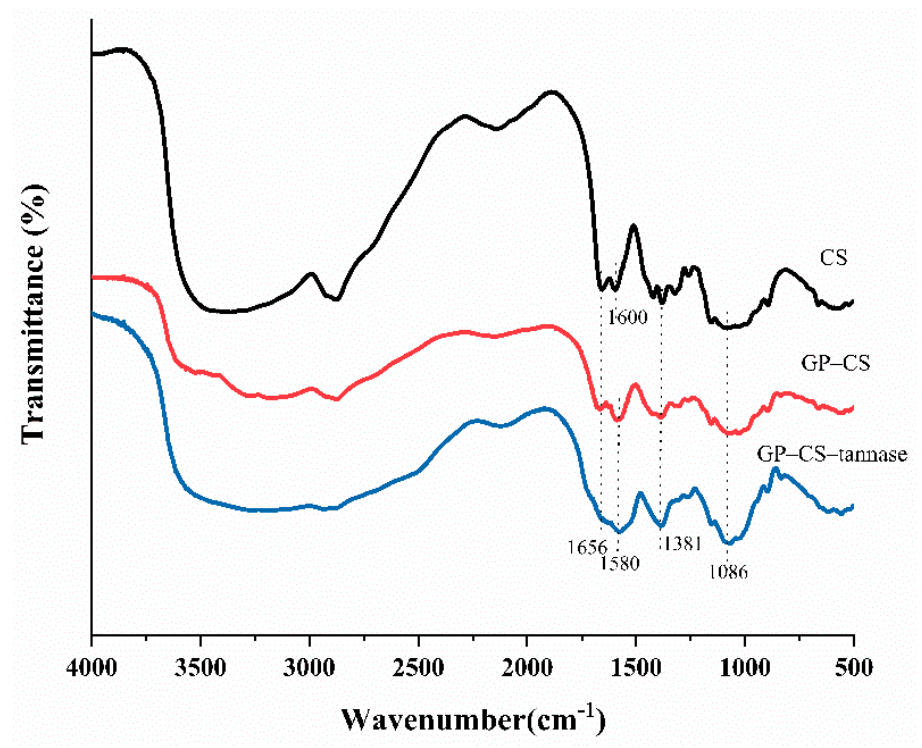

Figure 2. FTIR analysis of the CS, GP-CS, and GP-CS-tannase.

\subsection{TGA Analysis}

Figure 3 shows the TGA profiles of CS, GP-CS, and GP-CS-tannase. Weight loss in CS, GP-CS, and GP-CS-tannase occurred in three main temperature phases. Weight loss was observed in all samples when the temperature reached $100^{\circ} \mathrm{C}$ due to the elimination of adsorbed water from the surface [24]. Chitosan particles (CS) showed a low weight loss rate of only $7.64 \%$ in this region compared with GP-CS (9.65\%) and GP-CS-tannase $(10.08 \%)$, indicating the low hydrophilicity of CS. Chitosan showed high thermal stability at temperatures of up to $240^{\circ} \mathrm{C}$ and exhibited significant weight loss at temperatures ranging from $270{ }^{\circ} \mathrm{C}$ to $400{ }^{\circ} \mathrm{C}$. This decomposition step can be ascribed to the complex dehydration, depolymerization, and pyrolytic decomposition of the polysaccharide structure (C-O-C and C-C bonds) [57], and to the evaporation and elimination of volatile products [24,58,59]. The weight loss rates from $180^{\circ} \mathrm{C}$ to $400{ }^{\circ} \mathrm{C}$ for GP-CS pellets and GP-CS-tannase were $46.3 \%$ and $51.5 \%$, respectively. In this temperature range, weight loss can be attributed to the weakening of chitosan structures after GP crosslinking. The total weight loss rates of GP-CS and GP-CS-tannase were $83.1 \%$ and $98.3 \%$, respectively, as indicated by the TGA curve, suggesting that $15.2 \%$ of tannase was immobilized on the surface of GP-CS. Furthermore, the TGA curves showed that the chitosan particles obtained were thermally stable in the temperature range used for most enzymatic reactions.

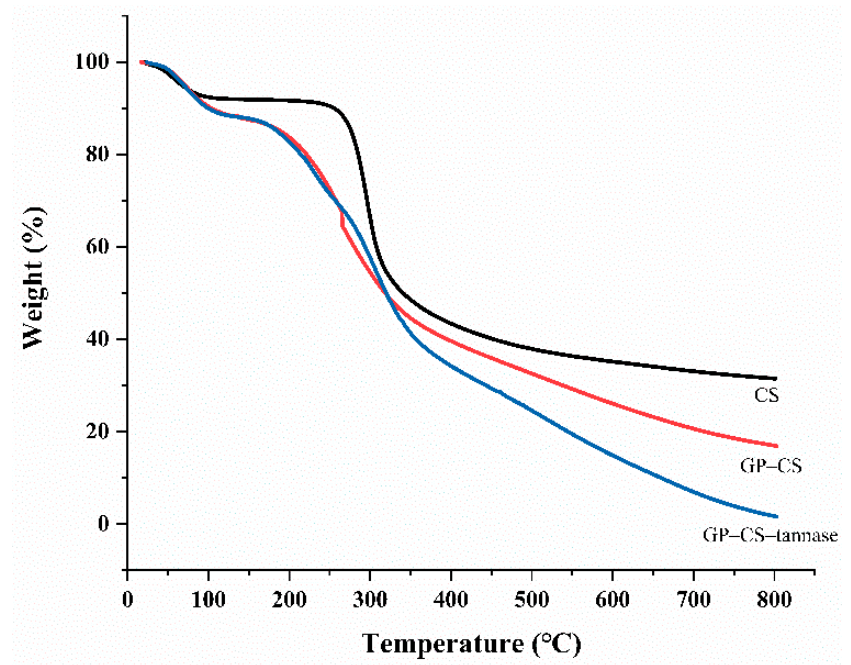

Figure 3. TGA analysis of CS, GP-CS, and GP-CS-tannase. 


\subsection{Determination of the Working Conditions for Tannase Immobilization}

To obtain insights into the effect of immobilization conditions on the activity recovery of tannase after immobilization with GP-CS, we conducted a series of investigations. The effect of initial enzyme concentration on GP-CS-tannase activity is shown in Figure 4a. The highest recovery rate $(31.15 \%)$ was achieved at a low tannase addition of $5 \mathrm{U}$. As the amount of tannase increased, the enzyme recovery rate gradually decreased, and the enzyme activity gradually increased. Considering the enzyme recovery rate and enzyme activity, we set the initial enzyme amount at $10 \mathrm{U}$. Under this condition, the recovery rate and enzyme activity were $25.7 \%$ and $14.1 \mathrm{U} / \mathrm{g}$, respectively.
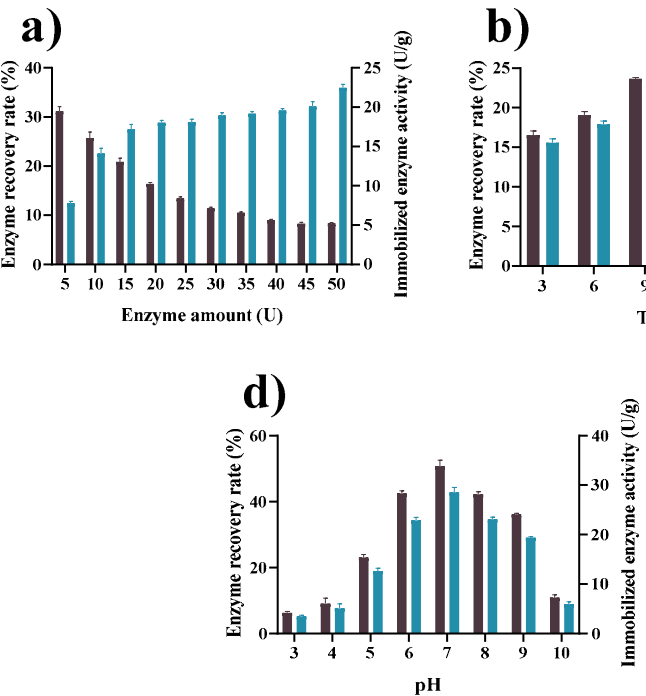
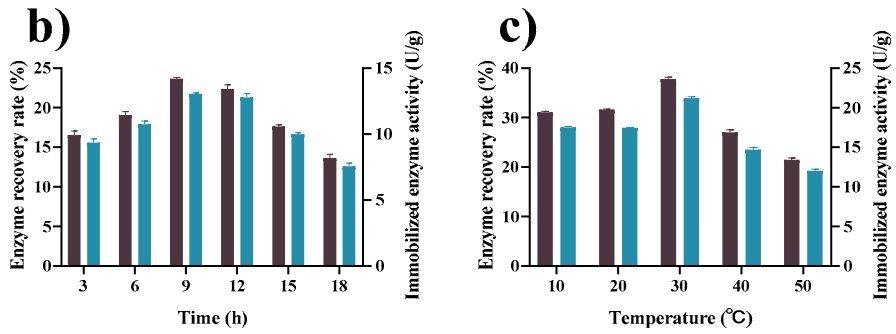

Figure 4. Effects of (a) enzyme amount (5-50 U), (b) immobilization time (3-18 h), (c) immobilization temperature $\left(10-50^{\circ} \mathrm{C}\right),(\mathrm{d})$ immobilization $\mathrm{pH}$ (Citrate buffer at $\mathrm{pH} 3.0-6.0$, phosphate at $\mathrm{pH}$ 6.0-8.0, Tris- $\mathrm{HCl}$ buffer at $\mathrm{pH} 8.0-9.0$, and $\mathrm{Gly}-\mathrm{NaOH}$ buffer at $\mathrm{pH} 9.0-10.0$ ), and (e) shaking speed (90-210 rpm/min) on the enzyme recovery rate ( $\square$ ) of immobilized tannase and the enzyme activity ( $\square$ ). Other immobilization conditions were carried out as in Section 3.3. The activity of immobilized enzyme was determined under standard conditions $\left(30^{\circ} \mathrm{C}\right.$, citrate buffer at $\mathrm{pH}$ 5.0). All data represent the mean \pm standard deviation of triplicate measurements.

To determine the optimum reaction time for immobilization, we measured the enzyme recovery rate and activity of the immobilized enzymes at reaction times of 3, 6, 9, 12, 15, and $18 \mathrm{~h}$. As shown in Figure $4 \mathrm{~b}$, when the reaction time was $9 \mathrm{~h}$, enzyme activity and activity recovery reached their highest values (13.1 U/g and 23.7\%, respectively). Enzyme activity and activity recovery gradually decreased with increasing immobilization time possibly due to the saturation of the reactive groups on the carrier, excessive physisorption, and the enzyme's spatial resistance [60].

To access the effect of temperature on immobilization, we immobilized with GP-CS at $10^{\circ} \mathrm{C}, 20^{\circ} \mathrm{C}, 30^{\circ} \mathrm{C}, 40{ }^{\circ} \mathrm{C}$, and $50^{\circ} \mathrm{C}$. Figure $4 \mathrm{c}$ shows that the recovery of activity and immobilized enzyme activity reached their highest values $(37.8 \%$ and $21.2 \mathrm{U} / \mathrm{g}$, respectively) at $15{ }^{\circ} \mathrm{C}$. With increasing temperature, immobilized tannase activity and recovery of activity gradually decreased probably due to the structural changes in GP-CS and tannase under high temperatures.

External $\mathrm{pH}$ influences the interaction between genipin and an enzyme, and the stability of enzymes [61]. To determine the optimum $\mathrm{pH}$ for the reaction between tannase and GP-CS, we set the $\mathrm{pH}$ values of the entire system to 3-10 and measured the enzyme recovery rate and activity of the immobilized enzymes at the end of the reaction. Figure $4 \mathrm{~d}$ shows that the activity recovery and immobilized enzyme activity of GP-CS immobilized tannase peaked at $\mathrm{pH} 7$ and had values of $50.8 \%$ and $28.5 \mathrm{U} / \mathrm{g}$, respectively. 
The optimum shaking speed (Figure 4e) for the immobilization reaction was determined by analyzing enzyme activity and activity recovery at different shaking speeds ranging from $90 \mathrm{rpm} / \mathrm{min}$ to $210 \mathrm{rpm} / \mathrm{min}$. The optimum values $(53.6 \%$ and $29.2 \mathrm{U} / \mathrm{g}$, respectively) of enzyme activity recovery and enzyme activity of the immobilized enzyme were observed at $150 \mathrm{rpm} / \mathrm{min}$. The effectiveness of immobilization decreased with increasing shaking speed. Therefore, the optimum oscillation speed for the immobilized enzyme was set at $150 \mathrm{rpm} / \mathrm{min}$. The optimized immobilization conditions of GP-CS-tannase were as follows: initial enzyme amount, $10 \mathrm{U}$; temperature, $15^{\circ} \mathrm{C} ; \mathrm{pH}, 7$; shaking speed, $150 \mathrm{rpm} / \mathrm{min}$. It is noteworthy that the optimal conditions resulted in $93.2 \%$ immobilization yield when the tannase activity was impaired probably due to aggregation, unfavorable protein conformational changes, or steric hindrance to the active site. The immobilization yield and activity recovery rate were similar to other reports about enzyme immobilization with activated chitosan beads.

\subsection{Enzymatic Properties of Tannase and GP-CS-Tannase}

The $\mathrm{pH}$ of the catalytic environment significantly affects the reaction catalyzed by an enzyme [62]. As can be seen in Figure 5a, the optimum pH of the immobilized tannase was 6 and shifted toward a neutral $\mathrm{pH}$. In addition, the activity of GP-CS-tannase was higher than that of free tannase between $\mathrm{pH} 6.0$ and 10.0, indicating that the immobilized tannase was less sensitive to environmental $\mathrm{pH}$ than free tannase. Tannase has a broader $\mathrm{pH}$ range of activity when immobilized than free enzymes [22,63]. Change in $\mathrm{pH}$ may be due to a reduction in the number of the positively charged groups of enzymes associated the carriers' amino groups after immobilization. As a result, the enzymes become polyanionic. The $\mathrm{pH}$ stability of free tannase and immobilized tannase was assessed in the $\mathrm{pH}$ range of 3.0-10.0. As shown in Figure 5b, the immobilized tannase was more stable than the free tannase at $\mathrm{pH} 3-8$. At $\mathrm{pH}$ ranging from 3 to 8 , the discrepancy between the maximum and minimum values of the residual enzyme activity of the immobilized enzyme was only $33.4 \%$, whereas the discrepancy reached $78.2 \%$ for the free enzyme. These results can be explained by the protective effects of the microenvironment of the immobilized carrier and the buffering effect of the carrier microenvironment; these effects improve the $\mathrm{pH}$ stability of immobilized enzymes [22].

Optimum temperature is essential to the biotransformation reaction of an enzyme [64] The ionic states of amino acids forming the active sites of enzymes may be influenced by temperature. The general unfolding of protein structures may occur, leading to the inactivation of the enzymes [22]. The optimum temperatures for free and immobilized tannase were $80^{\circ} \mathrm{C}$ and $50{ }^{\circ} \mathrm{C}$, respectively (Figure $5 \mathrm{c}$ ), which differed from the majority of immobilized enzymes in raising the optimum temperature. The lower optimum temperature reduces the energy consumption of the catalytic process and indicates that immobilization reduces the activation energy of the reaction. We speculate that this is due to the high thermal adaptability of the tannase itself and that the main limiting factor for the catalytic reaction after immobilization shifts to the efficiency of substrate delivery in the enzyme-carrier system. The optimum temperature for immobilized tannase was reduced relative to that of a free enzyme, but immobilization afforded the enzyme with a board temperature range that was $89.8 \%$ of that of the relative activity $\left(40-90^{\circ} \mathrm{C}\right)$, probably due to the protective effect of chitosan carrier on the tannase structure [65].

The thermal stability of tannase is critical for its industrial application. Figure $5 d-f$ showed the residual enzyme activities of free and immobilized tannase after treatment at $50{ }^{\circ} \mathrm{C}, 60{ }^{\circ} \mathrm{C}$, and $70{ }^{\circ} \mathrm{C}$. Free and immobilized tannase retained $55.7 \%$ and $58.5 \%$ of relative activity, respectively, after $120 \mathrm{~h}$ of incubation at $50{ }^{\circ} \mathrm{C}$ and retained $34.0 \%$ and $57.2 \%$, respectively, after $12 \mathrm{~h}$ at $60^{\circ} \mathrm{C}$. However, their activities were gradually lost at high temperatures. Notably, immobilized tannase was slightly less sensitive to high temperatures. The half-life of immobilized tannase at $70{ }^{\circ} \mathrm{C}$ was $52.7 \mathrm{~min}$, which was 1.59 -fold that of free tannase. The thermal stability of immobilized enzymes usually improves [66-69] 
due to their interactions with carriers; these interactions inhibit conformational freedom and the thermal vibrations of peptides [66].
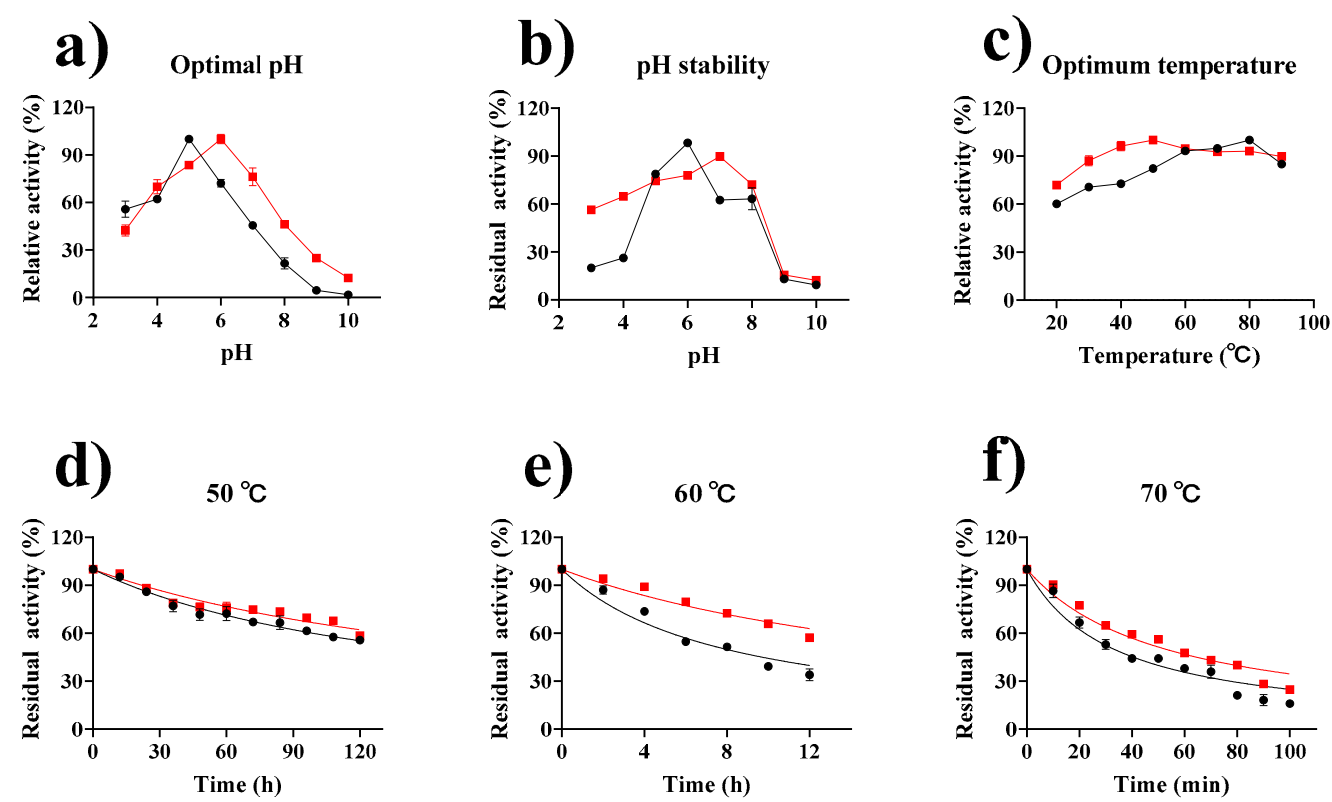

Figure 5. Effects of $\mathrm{pH}$ and temperature on the activity and stability of tannase ( $\bullet-)$ and GP-CStannase (-). (a) The optimal $\mathrm{pH}$ For Tannase was determined by performing an activity assay with four different buffers $(50 \mathrm{mM})$ at $\mathrm{pH} 3.0-10.0$, citrate buffer at $\mathrm{pH} 3.0-6.0$, phosphate at $\mathrm{pH}$ 6.0-8.0, Tris- $\mathrm{HCl}$ buffer at $\mathrm{pH}$ 8.0-9.0, and Gly-NaOH buffer at $\mathrm{pH} 9.0-10.0$. (b) The $\mathrm{pH}$ stability of Tannase was determined during incubation at different $\mathrm{pH}$ values and $4{ }^{\circ} \mathrm{C}$ for $24 \mathrm{~h}$. (c) The determination of the optimum temperatures for free and immobilized tannase at different temperatures and at $\mathrm{pH} 5.0$ and 6.0. (d-f) The thermal stability of free and immobilized tannase was determined after incubation at $50{ }^{\circ} \mathrm{C}, 60^{\circ} \mathrm{C}$, and $70^{\circ} \mathrm{C}$. The half-life was obtained by fitting with GraphPad Prism software. All data represent the mean \pm standard deviation of triplicate measurements.

\subsection{Reusability and Storage Stability of GP-CS-Tannase}

The reusability of the enzyme was considered one of the paramount advantages of immobilized enzymes. The reusability of GP-CS-tannase was evaluated by implementing 12 continuous recycles. GP-CS-tannase retained $46.1 \%$ of the initial activity after six recycles and retained $20.1 \%$ of the initial activity after 12 cycles (Figure 6a). Storage stability is a fundamental criterion for the performance of immobilized biocatalysts for preparative or industrial use. The storage stability of free and immobilized tannase was investigated by measuring residual activity for 30 days (Figure 6b). GP-CS-tannase retained higher $(81.12 \%)$ residual activity than free tannase $(60.37 \%)$ throughout the testing period.

\subsection{Effect of Extraction Temperature and Time on Catechins in Green Tea}

Given the significant loss of immobilized enzyme activity at $80^{\circ} \mathrm{C}$, the tea extract was treated at $30-70{ }^{\circ} \mathrm{C}$ for $1 \mathrm{~h}$. Samples were collected at $10 \mathrm{~min}$ intervals for the analysis of catechin composition. The results are shown in Figure 7. The conversion rates of ester-type catechins (ECG and EGCG) to non-ester-type catechins (EC and EGC) by tannase increased with temperature (Figure 7a,b). The concentration of GA was also increased with temperature (Figure $7 \mathrm{c}$ ) due to the accelerated reaction rate. The degradation rate of ECG in tea extracts treated at $70{ }^{\circ} \mathrm{C}$ reached $62.7 \%$ at 60 min of extraction, exhibiting an enhancement of $36.3 \%$ compared with that at $30{ }^{\circ} \mathrm{C}$ (Figure $7 \mathrm{~b}$ ). Notably, the degradation rate of EGCG reached more than $95 \%$ after 10 min of interaction with tannase at any temperature (Figure 7a). At $70{ }^{\circ} \mathrm{C}$, the concentration of EGC reached $799.4 \mathrm{mg} / \mathrm{L}$, showing an increase of $1758 \%$ relative to that of the untreated tea extract (Figure $7 \mathrm{~d}$ ). The concentration of EC reached $306.1 \mathrm{mg} / \mathrm{L}$ after $10 \mathrm{~min}$ at $70{ }^{\circ} \mathrm{C}$ and gradually decreased with further treatment 
(204.2 $\mathrm{mg} / \mathrm{L}, 60 \mathrm{~min}$ ) (Figure 7e). We speculated that the possible reason for the decreased $\mathrm{EC}$ is the adsorption effect on EC. The adsorption experiment was carried out. The result (Figure $7 \mathrm{f}$ ) showed that the concentration of the EC standard solution decreased from $149.5 \mathrm{mg} / \mathrm{L}$ to $27.5 \mathrm{mg} / \mathrm{L}$ due to the adsorption of $122.0 \mathrm{mg} / \mathrm{L} \mathrm{GP}-\mathrm{CS}$, thereby supporting our hypothesis. The catechins composition analysis indicated that the concentration of non-ester-type catechins, EGC and EC, were increased by $1758 \%$ and $807 \%$, respectively, after enzymatic treatment.
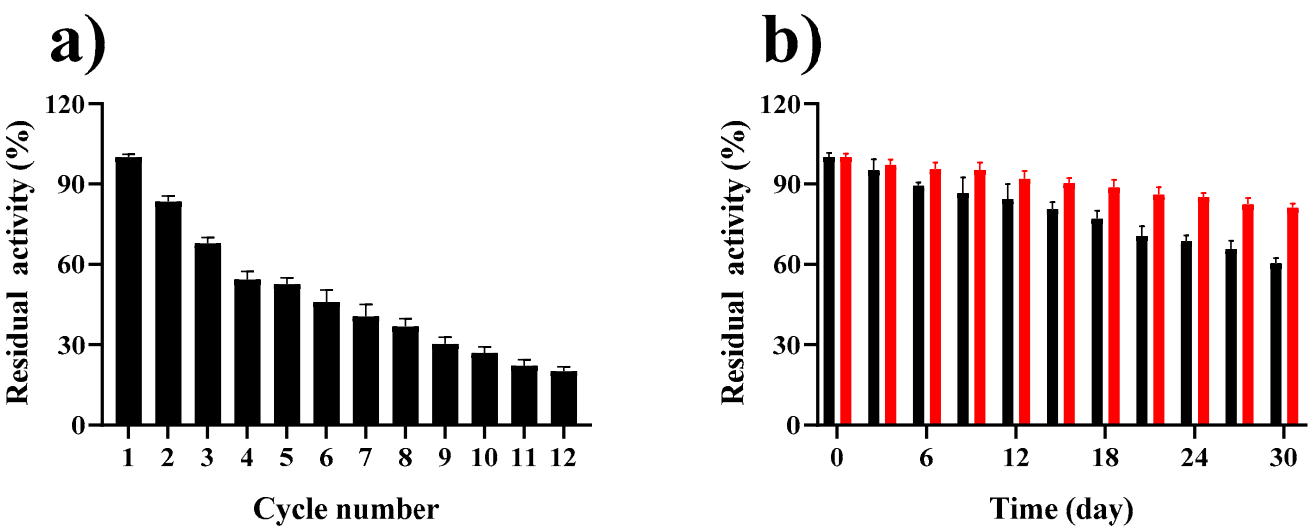

Figure 6. Reusability and storage stability of GP-CS-tannase. (a) The reaction was performed at $50{ }^{\circ} \mathrm{C}$ for $5 \mathrm{~min}$ with $50 \mathrm{mM}$ citrate buffer ( $\mathrm{pH}$ 6.0). Residual activity was presented as a percentage of initial enzyme activity under experimental conditions. All data represent the mean \pm standard deviation of triplicate measurements. (b) Tannase $(\mathbf{\square})$ and GP-CS-tannase ( $\square$ ) were stored at $4{ }^{\circ} \mathrm{C}$, and their activities were measured under optimal conditions after removal every 3 days. The residual activities of the free and immobilized enzymes were presented as a percentage of initial enzyme activities. All data represent the mean \pm standard deviations of triplicate measurements.
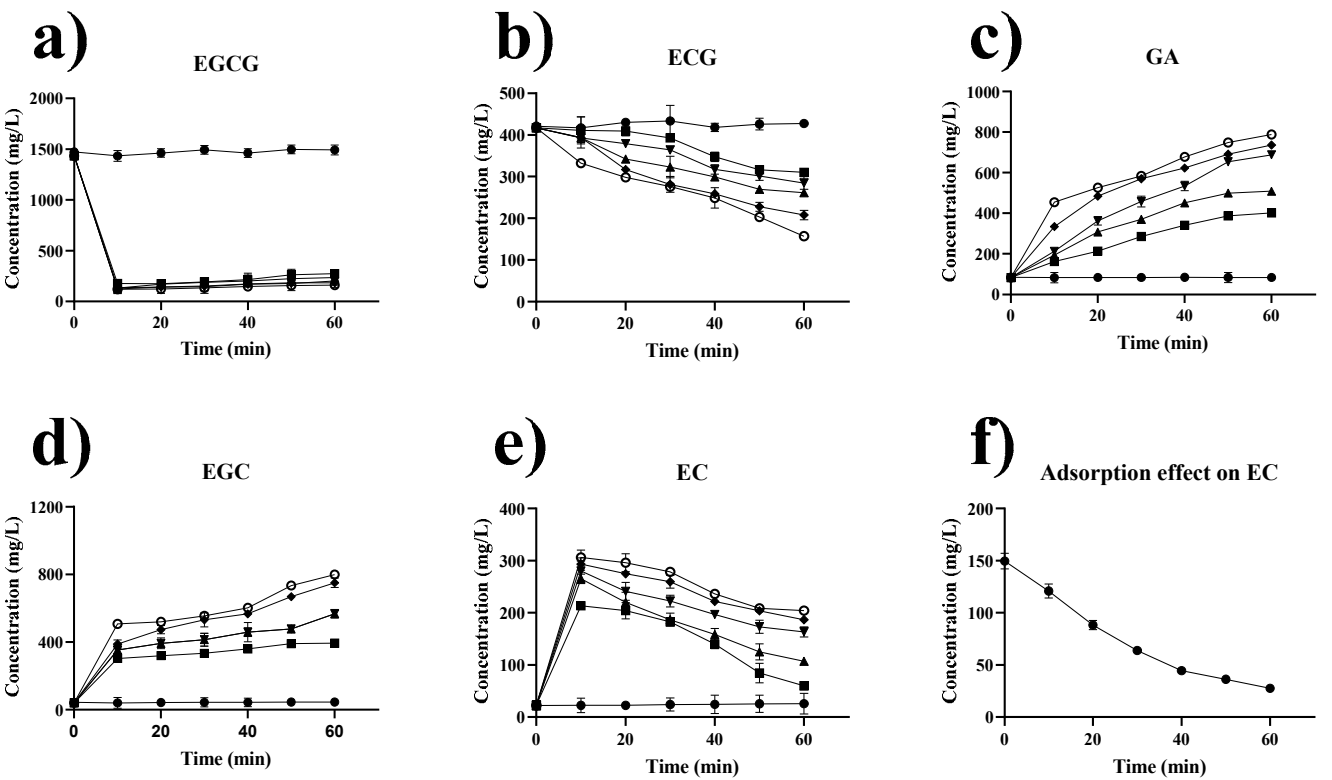

Figure 7. Effect of extraction temperature and time on catechins in green tea. (a) EGCG, (b) ECG, (c) GA, (d) EGC, (e) EC, and (f) adsorption effect on EC. The legend in Figure (a-e) is as follows: untreated tea extract $(\bullet), 30{ }^{\circ} \mathrm{C}(\boldsymbol{\square}), 40{ }^{\circ} \mathrm{C}(\boldsymbol{\Delta}), 50{ }^{\circ} \mathrm{C}(\boldsymbol{\nabla}), 60{ }^{\circ} \mathrm{C}(\bullet)$, and $70{ }^{\circ} \mathrm{C}(\bigcirc)$; $0.5 \mathrm{~g}$ of GP-CStannase was added to $10 \mathrm{~mL}$ of tea extract, and enzyme activity was $12.5 \mathrm{U}$. All data represent the mean \pm standard deviation of triplicate measurements. 


\subsection{Effect of Tannase Treatment on the Biological Activity of Tea Extracts}

\subsubsection{Effect of Enzymatic Treatment on the Total Phenols of Tea Extracts}

Phenol content affects the antioxidant activity of tea extracts. Bursal et al. found that total phenol content was related to iron reduction ability [70]. Ranilla et al. found correlations between phenolic components and antioxidant activity in several traditional medicinal plants, herbs, and spices in Latin America [71]; Castiglioni et al. explored the correlation between phenolics and antioxidant activity in tea by adjusting steeping conditions (time, temperature, and particle size) [72]. As shown in Figure 8a, enzymatic treatment can increase total phenolic content. When the tea extract was added at a volume of $5 \mathrm{~g} / \mathrm{L}$, the total phenolic contents in tea extracts treated with free enzymes and immobilized tannase were enhanced by $9.6 \%$ and $12.1 \%$, respectively, compared with the total phenolic content of untreated tea extract.
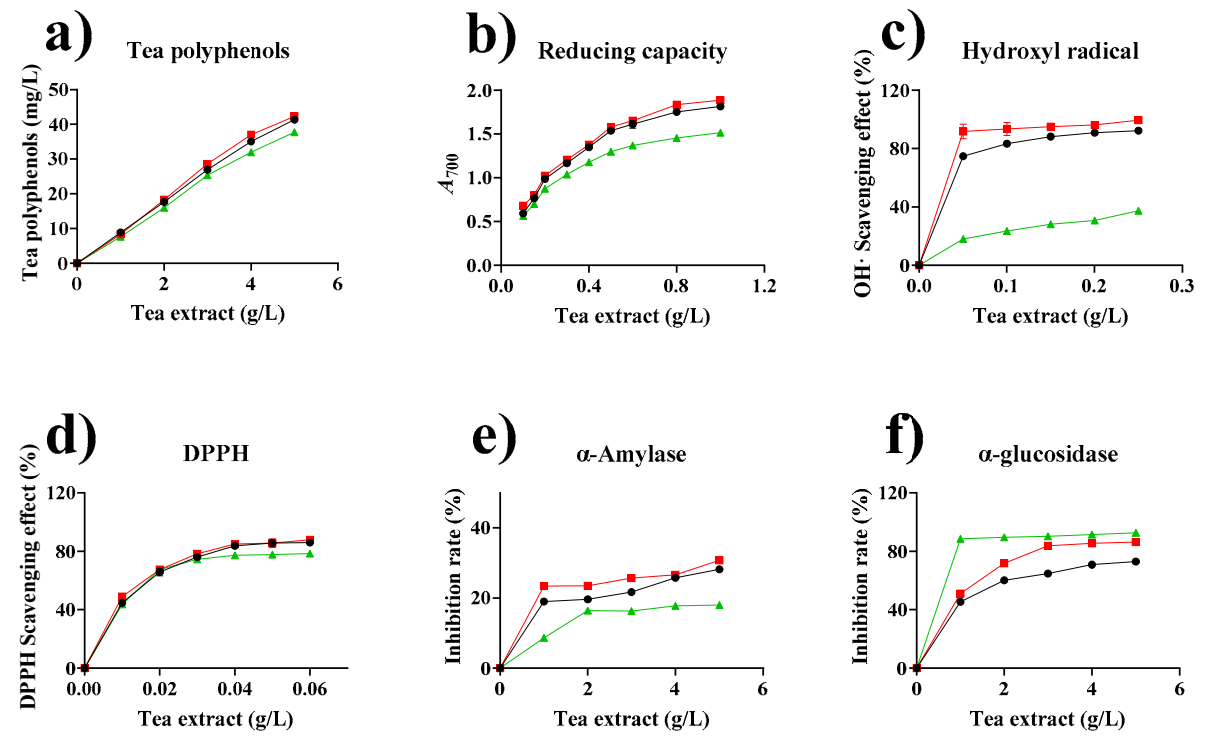

Figure 8. Effect of tannase treatment on the biological activities of tea extract. (a) Tea polyphenols. (b) Reducing capacity. (c) Hydroxyl radical-scavenging effect. (d) DPPH-scavenging effect. (e) Inhibition rate of $\alpha$-amylase. (f) Inhibition rate of $\alpha$-glucosidase. $(\bullet),(\square)$, and $(\Delta)$, represent tannase-treated, GP-CS-tannase-treated, and untreated tea extracts, respectively. All data represent the mean \pm standard deviation of triplicate measurements.

\subsubsection{Effect of Enzymatic Treatment on the Reducing Capacities of Tea Extracts}

Reduction in $\mathrm{Fe}^{3+}$ is an indicator of a phenol's antioxidant activity [73]. Figure $8 \mathrm{~b}$ demonstrates that all the tea extracts reduced iron ions, indicating a dose-effect association between tea concentration and reducing capacity. When the tea extract concentration was increased from $0.1 \mathrm{~g} / \mathrm{L}$ to $1.0 \mathrm{~g} / \mathrm{L}$, the optical density (OD) value of immobilized tannase-treated tea extract increased from 0.682 to 1.885 , whereas the OD value of free tannase-treated tea extract increased from 0.593 to 1.815 . Meanwhile, the OD value of untreated tea extract increased from 0.565 to 1.516 . The scavenging activities of tannasetreated tea extracts were higher than those of the untreated tea extracts. The reducing capacity of the immobilized enzyme-treated tea extract was slightly higher than that of the free enzyme group.

\subsubsection{Hydroxyl Radical-Scavenging Effect of Tea Extract}

Hydroxyl radicals catalyzed by hydrogen peroxide cause lipid peroxidation, massive oxidative protein degradation, and DNA damage and are involved in human pathology and aging [74]. The scavenging effects of different concentrations of tea extracts on hydroxyl radicals are shown in Figure 8c. The scavenging effects of enzyme-treated tea extracts on hydroxyl radicals were significantly higher than those of the non-enzyme-treated tea 
extracts. When $0.25 \mathrm{~g} / \mathrm{L}$ tea extract was added, the scavenging capacities of free enzyme, immobilized enzyme, and control group reached $92.3 \%, 99.5 \%$, and $37.5 \%$, respectively. The enzyme-treated tea extracts significantly improved the scavenging of hydroxyl radicals because of the improved bioactivity of the tea broth after the structural transformation of catechins.

\subsubsection{Antioxidant Activity by DPPH Radical Scavenging Assay}

DPPH radicals can accept electrons or hydrogen radicals and eventually become stable anti-magnetic molecules, which can be used as substrates for the evaluation of the ability of antioxidants to scavenge free radicals [75]. As shown in Figure 8d, the DPPH radicalscavenging ability of a tea extract increased with the amount of the tea extract. Polyphenols and catechins are closely associated with DPPH free radical scavenging activity. Tannase catalyzes the hydrolysis of ester catechin, which improves the free radical scavenging activities of tea extracts against superoxide anion, hydrogen peroxide, and DPPH [75,76]. The DPPH radical-scavenging ability of the enzyme treated tea extract was slightly higher than that of the untreated group. Tea extracts prepared with free and immobilized tannase showed similar DPPH radicals scavenging abilities. The order of DPPH radical scavenging activities of catechins is EGCG > ECG > EGC > EC [77].

\subsubsection{Inhibitory Effect on $\alpha$-Amylase and $\alpha$-Glucosidase Activities}

The inhibitory activity of the tea extract on $\alpha$-amylase is shown in Figure $8 \mathrm{e}$. The inhibitory effect of $\alpha$-amylase increased with tea extract concentration. We found that at a concentration of $5 \mathrm{~g} / \mathrm{L}$, the inhibition rate of the tea extract without enzyme treatment was $18.0 \%$ for $\alpha$-amylase, whereas the inhibition rates of the immobilized and free enzyme-treated tea extracts were $30.8 \%$ and $28.2 \%$, respectively, which were enhanced by $56.4 \%$ and $70.5 \%$, respectively, compared to the inhibition rate of the untreated tea extract. The inhibitory activities of tea extracts against $\alpha$-amylase is related to the formation of hydrogen bonds between hydroxyl radicals and the catalytic residues of $\alpha$-amylase and to the formation of conjugated $\pi$-systems, which stabilize interactions with active sites [78]. Ester-type catechins (EGCG and ECG) have a high binding affinity for $\alpha$-amylase active site residues, thus inhibiting $\alpha$-amylase activity [79]. However, high concentrations of tea polyphenols inhibit $\alpha$-amylase activity in a non-competitive manner [80]. This finding is consistent with the results obtained in the current experiment. Moreover, ECG and EGCG are weakly correlated with $\alpha$-amylase inhibitory activity [81].

The inhibitory effects of tea extracts on $\alpha$-glucosidase activity were investigated using a colorimetric method (Figure $8 \mathrm{f}$ ). When $1.0 \mathrm{~g} / \mathrm{L}$ tea extract was added, the scavenging capacities of free enzyme, immobilized enzyme, and control group reached $45.4 \%, 51.2 \%$, and $88.5 \%$ respectively. The enzymatic treatment of tea extract reduced inhibitory effects on $\alpha$-glucosidase. Moreover, $\alpha$-glucosidase inhibitory activity was correlated with EGCG and ECG concentrations. Qu et al. reported that EGCG had the strongest inhibitory effect on $\alpha$-glucosidase activity, followed by ECG [82]. This result is consistent with the catechin composition analysis results, which showed that the treatment of tea extracts with tannase transformed ester-type catechins (EGCG and ECG) into non-ester-type catechins (EGC and $\mathrm{EC})$.

$\alpha$-Amylase and $\alpha$-glucosidase are important inhibitory targets for type 2 diabetes. The inhibition of these hydrolytic enzymes can suppress postprandial hyperglycemia for the management of type 2 diabetes. Plant-based extracts are considered promising and effective inhibitors for $\alpha$-amylase and $\alpha$-glucosidase [83]. The experimental results showed that the untreated and treated tea extract exhibited certain concentration-dependent inhibitory effects on $\alpha$-amylase and $\alpha$-glucosidase. The inhibitory effect of tea extract on amylase were ranked as follows: GP-CS-tannase-treated, free tannase-treated, and untreated tea extracts. The inhibitory effects of tea extracts on glucosidase were ranked as follows: untreated, GP-CS-tannase-treated, and free tannase-treated tea extracts. The inhibitory effect of $\alpha$-glucosidase was greater than that of $\alpha$-amylase. This difference in inhibitory 
effect between $\alpha$-amylase and $\alpha$-glucosidase causes undigested carbohydrates to enter the colon, leading to intestinal bacterial fermentation and subsequent intestinal diseases, such as abdominal pain, flatulence, and diarrhea [84]. After enzymatic treatment, the inhibitory effects of the tea extracts on $\alpha$-amylase considerably improved, whereas the inhibitory effects on $\alpha$-glucosidase significantly decreased. This decrease may reduce the risk of intestinal diseases.

\section{Materials and Methods}

\subsection{Materials and Strain}

Propyl gallate (PG), rhodanine, tannic acid (TA), and Gallic acid (GA) were purchased from TCI (Shanghai, China). Acetonitrile (HPLC analytical grade) and acetic acid (HPLC analytical grade) were purchased from Sigma Aldrich (Milan, Italy), and 4-nitrophenyl- $\alpha$-D-glucopyranoside (pNPG), folin, $\alpha$-glucosidase, epigallocatechin gallate (EGCG), epigallocatechin (EGC), epicatechin gallate (ECG), epicatechin (EC), 1,1diphenyl-2-picrylhydrazine (DPPH), genipin, and chitosan were purchased from Yuanye Bio-Technology (Shanghai, China).

Tannase from Aspergillus oryzae FJ0123 was expressed in Pichia pastoris GS115 and stored in the Key Laboratory of Food Microbiology and Enzyme Engineering of Fujian Province (Jimei University, Xiamen, China).

\subsection{Preparation and Activation of Chitosan Beads}

Chitosan beads were prepared and activated with genipin according to a previously report with minor modifications [33]. In brief, a $4 \%(w / v)$ solution of chitosan was first prepared with a $2 \%$ solution of acetic acid, then added dropwise to $2 \mathrm{~N} \mathrm{NaOH}$ for the coagulation.

Chitosan beads were activated with genipin as an activate agent at different conditions, such as concentrations $(0.4 \%, m / v)$, activation temperatures $\left(10^{\circ} \mathrm{C}\right)$, activation $\mathrm{pH}(3)$, and activation time $(3 \mathrm{~h})$, at a speed of $150 \mathrm{rpm} / \mathrm{min}$. After the activation step, excess genipin was washed off with $200 \mathrm{~mL}$ of deionized (DI) water and stored at $4{ }^{\circ} \mathrm{C}$ until use.

\subsection{Enzymatic Immobilization}

Approximately $10 \mathrm{U}$ of tannase was added to $50 \mathrm{mM}$ phosphate buffer (pH 7.0) with $200 \mathrm{mg}$ of chitosan beads and incubated at $30^{\circ} \mathrm{C}$ and $150 \mathrm{rpm} / \mathrm{min}$ for $9 \mathrm{~h}$. The carriers were then separated from the solution and washed five times with DI water for the removal noncovalently bonded proteins. The immobilized tannase was stored at $4{ }^{\circ} \mathrm{C}$.

\subsection{Activity Assay}

Tannase activity was determined with a chromogen formation method using gallic acid and rhodanine (2-thioxo-4-ketothiazolidine) [85]. Absorbance was recorded at $520 \mathrm{~nm}$ for the experimental and inactivated enzyme groups. Enzyme activity was defined as the amount of enzyme required to catalyze the production of $1 \mu \mathrm{mol}$ of gallic acid per minute at $30{ }^{\circ} \mathrm{C}$ as one unit of enzyme activity.

The immobilization parameters were calculated as follows:

Activity recovery $(\%)=($ Biocatalyst activity $(\mathrm{U})) /($ Intital activity $(\mathrm{U})) \times 100$

Immobilized activity $(\mathrm{U} / \mathrm{g})=($ Biocatalyst activity $(\mathrm{U})) /($ weight $(\mathrm{g}))$

\subsection{Characterization of CS, GP-CS, and GP-CS-Tannase by FT-IR and TGA}

CS, GP-CS, and GP-CS-tannase were completely dried through vacuum freezing and used for FT-IR and TGA analysis. The samples were ground with KBr (1:100 ratio) in a mortar and pestle for 3-4 min and then made into flakes with a hydraulic press. Infrared spectral data were collected with an FTIR spectrometer (Thermo Fisher Nicolet, iS10, Waltham, MA, USA) in a range of $4000-400 \mathrm{~cm}^{-1}$ with 16 -scan interferogram at $4 \mathrm{~cm}^{-1}$ resolution. 
TGA was performed using a TG/DSC instrument (TA, SDT Q600, New Castle, DE, USA) under air/N2 flow $\left(60 \mathrm{~mL} \mathrm{~min}{ }^{-1}\right)$; the heating rate was $10{ }^{\circ} \mathrm{C} \mathrm{min}-1$ and the temperature range was $30-800{ }^{\circ} \mathrm{C}$.

\subsection{Assessment of Enzymatic Characteristics, Reusability, and Storage Stability}

The effect of $\mathrm{pH}$ on the activities of the free and immobilized tannase was investigated and measured after reaction $\mathrm{pH}$ was adjusted from 5.0 to 11.0. Four different buffers (50 mM) at $\mathrm{pH} 3.0-10.0$, citrate buffer at $\mathrm{pH} 3.0-6.0$, phosphate at $\mathrm{pH}$ 6.0-8.0, Tris- $\mathrm{HCl}$ buffer at $\mathrm{pH}$ 8.0-9.0, and Gly- $\mathrm{NaOH}$ buffer at $\mathrm{pH} 9.0-10.0$. Relative activity at the optimum $\mathrm{pH}$ for the free and immobilized tannase was taken as $100 \%$. All reactions were performed in triplicate.

To assess the $\mathrm{pH}$ stability of the free and immobilized enzymes, we incubated tannase at different $\mathrm{pH}(3.0-10.0)$ for $24 \mathrm{~h}$ at $4{ }^{\circ} \mathrm{C}$. The residual activities of the enzymes were measured after incubation. The initial activities of the free and immobilized tannase were taken as $100 \%$. All reactions were performed in triplicate.

The effect of temperature on the activities of the free and immobilized tannase was investigated and measured at reaction temperatures of $20-90^{\circ} \mathrm{C}$. Relative activity at optimum temperature for the free and immobilized tannase was taken as $100 \%$. All reactions were performed in triplicate.

To assess the thermal stability of the free and immobilized enzymes, we incubated tannase at different temperatures $\left(50-90^{\circ} \mathrm{C}\right)$ and times. The enzymes were withdrawn periodically for the measurement of their residual activities. The initial activities of the free and immobilized tannase were taken as $100 \%$. All reactions were performed in triplicate.

To assess the reusability of the immobilized tannase, we performed the continuous enzymatic hydrolysis of PG with immobilized tannase. Immobilized enzyme was withdrawn after each reaction with PG for $5 \mathrm{~min}$, washed three times with citrate buffer $(50 \mathrm{mM}$, $\mathrm{pH}$ 5.0), and added to a PG solution for the reaction of next cycle. Residual activity was calculated by taking the activity of the first cycle as $100 \%$. All reactions were performed in triplicate.

To assess the storage stability of the immobilized tannase, we stored free and immobilized tannase at $4{ }^{\circ} \mathrm{C}$. The residual activities of the free and immobilized tannase were measured every 3 days. The activity measured on the first day was taken as $100 \%$ for the calculation of residual activities. All reactions were performed in triplicate.

\subsection{Treatment of Tea Extracts with GP-CS-Tannase}

Green tea powder ( $2 \mathrm{~g}, 40$ mesh) was extracted in a tea/water ratio of $1: 50$ at $100{ }^{\circ} \mathrm{C}$ for $20 \mathrm{~min}$, and immediate filtration in a $100 \mathrm{~mL}$ volumetric flask was performed. For enzymatic treatment, $0.5 \mathrm{~g}$ of GP-CS-tannase $(12.5 \mathrm{U})$ was added to each $10 \mathrm{~mL}$ of tea extract. The reaction temperatures $\left(30^{\circ} \mathrm{C}, 40^{\circ} \mathrm{C}, 50{ }^{\circ} \mathrm{C}, 60^{\circ} \mathrm{C}\right.$, and $\left.70{ }^{\circ} \mathrm{C}\right)$ and reaction times $(0,10,20,30,40,50$, and $60 \mathrm{~min})$ were adjusted and the samples were inactivated by boiling and centrifuged for $30 \mathrm{~s}(12,000 \mathrm{rpm})$ for HPLC analysis.

\subsection{Catechin Composition and Total Polyphenol Content Analysis of Tea Extracts}

Catechin composition was analyzed using high performance liquid chromatography (HPLC). The treated tea extract samples were filtered using a $0.22 \mu \mathrm{m}$ filter and then used in HPLC analysis. Catechin composition was determined at $30{ }^{\circ} \mathrm{C}$ and $280 \mathrm{~nm}$ with an HPLC column (Symmetry C 18, $5 \mu \mathrm{m}, 4.6 \mathrm{~mm} \times 250 \mathrm{~mm}$ ). Elution was performed by using phases A ( $0.5 \%$ aqueous acetic acid solution) and B (acetonitrile). The elution procedure was as follows: $6.5 \% \mathrm{~B}(0 \mathrm{~min}), 25 \% \mathrm{~B}(16 \mathrm{~min}), 6.5 \% \mathrm{~B}(30 \mathrm{~min})$, and $6.5 \% \mathrm{~B}(35 \mathrm{~min})$.

The total polyphenol content of the samples was determined using the Folin-Ciocalteu [71] method. Approximately $1 \mathrm{~mL}$ of sample was mixed with $1 \mathrm{~mL}$ of forintanol color developer and $5 \mathrm{~mL}$ of distilled water, and the mixture was incubated for $5 \mathrm{~min}$ at room temperature. Then, $3 \mathrm{~mL}$ of $\mathrm{Na}_{2} \mathrm{CO}_{3}(7.5 \%)$ was added for $60 \mathrm{~min}$ at room temperature with protection from light. The absorbance of each sample at $725 \mathrm{~nm}$ was measured, and 
the total polyphenol content was calculated according to the standard curve obtained by measuring a polyphenol standard. Gallic acid solution was used as the calibration curve. The result is expressed as $\mathrm{mg}$ gallic acid equivalent per $\mathrm{L}$ tea extract.

\subsection{Biological Activity Detection of Green Tea Extract}

\subsubsection{Determination of Reducing Power}

The reducing power of the tea extract was established using a previously described method [4] with minor modifications. Approximately $0.35 \mathrm{~mL}$ of phosphate buffer $(0.2 \mathrm{~mol} / \mathrm{L}$, $\mathrm{pH} 7.0), 0.15 \mathrm{~mL}$ of green tea extract, and $0.35 \mathrm{~mL}$ of $\mathrm{K}_{3} \mathrm{Fe}(\mathrm{CN})_{6}$ solution $(1 \%, m / v)$ were added to a $1 \mathrm{~mL}$ test tube, mixed, and incubated at $50{ }^{\circ} \mathrm{C}$ for $20 \mathrm{~min}$. After the solution was rapidly cooled with ice water, $0.35 \mathrm{~mL}$ of trichloroacetic acid solution $(10 \%, \mathrm{~m} / \mathrm{v})$ and $0.15 \mathrm{~mL}$ of $\mathrm{FeCl}_{3}$ solution $(0.1 \%, \mathrm{~m} / \mathrm{v})$ were added and mixed. Absorbance was measured at $700 \mathrm{~nm}$.

\subsubsection{Determination of Hydroxyl Radical-Scavenging Capacity}

The hydroxyl radical-scavenging activity was measured with the Fenton method [4] as described previously. In brief, $0.2 \mathrm{~mL}$ of green tea extract, $0.2 \mathrm{~mL}$ of $\mathrm{FeSO}_{4}(2.25 \mathrm{mM})$, $0.2 \mathrm{~mL}$ of $\mathrm{H}_{2} \mathrm{O}_{2}(8.8 \mathrm{mM})$, and $0.2 \mathrm{~mL}$ of salicylic acid ethanol solution $(9 \mathrm{mM})$ were mixed and incubated at $37^{\circ} \mathrm{C}$ for $30 \mathrm{~min}$. The absorbance of the reaction mixture was measured at $510 \mathrm{~nm}$. The scavenging capacities of the hydroxyl radicals were calculated as follows:

$$
\text { Scavenging activity }(\%)=(1-\mathrm{A} 1 / \mathrm{A} 0) \times 100
$$

where A0 and A1 represent the blank absorbance value (water was used instead of green tea extract) and the absorbance value of the sample, respectively.

\subsubsection{Determination of DPPH Radical-Scavenging Activity}

DPPH radical-scavenging activity was measured according to a previous method with minor modifications [86]. Approximately $0.5 \mathrm{~mL}$ of DPPH-ethanol solution $(0.2 \mathrm{mmol} / \mathrm{L})$ and $0.5 \mathrm{~mL}$ of green tea extract was mixed and allowed to react for $30 \mathrm{~min}$ at room temperature. Absorbance at $517 \mathrm{~nm}$ was assayed. DPPH radical-scavenging activity was measured according to the following equation:

$$
\text { Scavenging activity }(\%)=(1-\mathrm{A} 1 / \mathrm{A} 0) \times 100
$$

where A0 and A1 represent the blank absorbance value (95\% ethanol was used instead of green tea extract) and the absorbance value of the sample, respectively.

\subsubsection{Inhibition Effect on $\alpha$-Amylase}

$\alpha$-Amylase inhibitory effect was measured according to the report of Ranilla et al. [71]. Approximately $0.25 \mathrm{~mL}$ of $\alpha$-amylase $(0.05 \mathrm{mg} / \mathrm{mL})$ was mixed with $0.25 \mathrm{~mL}$ of green tea extract at $37{ }^{\circ} \mathrm{C}$ for $10 \mathrm{~min}$. Then, $0.5 \mathrm{~mL}$ of $0.5 \%(w / w)$ starch solution was added. The mixture was incubated at $37^{\circ} \mathrm{C}$ for $30 \mathrm{~min}$. After the reaction, $1 \mathrm{~mL}$ of DNS (3,5dinitrosalicylic acid reagent) was added. The mixture was boiled for $10 \mathrm{~min}$, cooled, and diluted to $10 \mathrm{~mL}$ with water, and the absorbance was measured at $540 \mathrm{~nm}$. The percentage of $\alpha$-amylase inhibition was calculated using the following formula:

$$
\text { Inhibition rate }(\%)=(1-\mathrm{A} 1 / \mathrm{A} 0) \times 100
$$

where $\mathrm{A} 0$ is the absorbance value of the blank (water was used instead of green tea extract) and $\mathrm{A} 1$ is the absorbance value of sample.

\subsubsection{Inhibition Effect on $\alpha$-Glucosidase}

$\alpha$-Glucosidase inhibitory effect was measured according to the report of Liu et al. [86]. Approximately $0.05 \mathrm{~mL}$ of $\alpha$-glucosidase solution and $0.05 \mathrm{~mL}$ of green tea extract were 
added to a 96-well plate and incubated at $37{ }^{\circ} \mathrm{C}$ for $15 \mathrm{~min}$. Then, $0.02 \mathrm{~mL}$ of pNPG substrate solution was added. The mixture was incubated at $37^{\circ} \mathrm{C}$ for another $15 \mathrm{~min}$. Absorbance at $410 \mathrm{~nm}$ was measured. Inhibition rate according to the following formula:

$$
\text { Inhibition rate }(\%)=(1-\mathrm{A} 1 / \mathrm{A} 0) \times 100
$$

where $\mathrm{A} 0$ is the absorbance value of blank (phosphate buffer was used instead of green tea extract) and $\mathrm{A} 1$ is the absorbance value of sample.

\subsection{Statistical Analysis}

All data represent the mean \pm standard deviations of triplicate measurements. Oneway analysis of variance (ANOVA) was used in analyzing the statistical significance of differences in each experiment. Data were processed using Origin (version 2019b) and GraphPad Prism (version 8.02).

\section{Conclusions}

We successfully constructed a non-toxic chitosan-based carrier for immobilizing of tannase and improving the biological activities of tea extracts. The preparation process of the immobilization strategy was optimized, and the characteristics of the immobilized enzyme were assessed. We also studied changes in catechin composition after tannase treatment. The results suggested that treating tea extracts with immobilized tannase can enhance their biological activities, including antioxidant activities and inhibitory effects on digestive enzymes. Overall, this study not only expands the application of chitosan in nontoxic immobilized carriers though genipin activation but also provides a novel strategy for the enzymatic treatment of tea extracts and enhancement of their biological activities.

Supplementary Materials: The following are available online at https:/ / www.mdpi.com/1660-339 7/19/3/166/s1, Figure S1: Immobilization yield and enzyme recovery rate of GP-CS-tannase and GA-CS-tannase.

Author Contributions: Conceptualization, C.W., Y.-H.Z., and A.-F.X.; methodology, Q.-M.Y. and H.-F.W.; investigation, C.W. and P.-X.C.; resources, Q.-M.Y. and H.-F.W.; writing-original draft preparation, C.W. and Y.-H.Z.; writing-review and editing, Y.-H.Z., Q.X., and A.-F.X.; visualization, C.W., P.-X.C., and Q.X.; supervision, Y.-H.Z. and A.-F.X.; project administration, A.-F.X.; funding acquisition, Y.-H.Z. and A.-F.X. All authors have read and agreed to the published version of the manuscript.

Funding: This work was supported by the National Natural Science Foundation of China (NSFC) (22008084), the Fujian Province Natural Science Foundation of China (2020J01680), Research Startup Funding of Jimei University (ZQ2019005, ZQ2020029), and Projects of the Incubation program for the National Natural Science Foundation (ZP2020032).

Institutional Review Board Statement: Not applicable.

Informed Consent Statement: Not applicable.

Conflicts of Interest: The authors declare no competing financial interests.

\section{References}

1. Jacqueline, S. Oakes, Investigation of Iron Reduction by Green Tea Polyphenols for Application in Soil Remediation. Master's Theses, University of Connecticut, Storrs, CT, USA, 19 December 2013.

2. Wu, S.C.; Wang, C.-W.; Hsu, L.-H.; Liang, C. Assessment of green tea reductive degradation of halogenated solvents. Chemosphere 2021, 267, 129196. [CrossRef] [PubMed]

3. Ryan, P.; Hynes, M.J. The kinetics and mechanisms of the complex formation and antioxidant behaviour of the polyphenols EGCg and ECG with iron(III). J. Inorg. Biochem. 2007, 101, 585-593. [CrossRef] [PubMed]

4. Li, J.; Xiao, Q.; Huang, Y.; Ni, H.; Wu, C.; Xiao, A. Tannase application in secondary enzymatic processing of inferior Tieguanyin oolong tea. Electron. J. Biotechnol. 2017, 28, 87-94. [CrossRef]

5. Rutter, P.; Stainsby, G. The solubility of tea cream. J. Sci. Food Agric. 1975, 26, 455-463. [CrossRef]

6. Farag, A.M.; Hassan, S.W.; El-Says, A.M.; Ghanem, K.M. Purification, Characterization and Application of Tannase Enzyme Isolated from Marine Aspergillus nomius GWA5. J. Pure Appl. Microbiol. 2018, 12, 1939-1949. [CrossRef] 
7. Koseki, T.; Otsuka, M.; Mizuno, T.; Shiono, Y. Mutational analysis of Kex2 recognition sites and a disulfide bond in tannase from Aspergillus oryzae. Biochem. Biophys. Res. Commun. 2017, 482, 1165-1169. [CrossRef] [PubMed]

8. Bhoite, R.N.; Murthy, P.S. Biodegradation of coffee pulp tannin by Penicillium verrucosum for production of tannase, statistical optimization and its application. Food Bioprod. Process. 2015, 94, 727-735. [CrossRef]

9. Gayen, S.; Ghosh, U. Purification and characterization of tannin acyl hydrolase produced by mixed solid state fermentation of wheat bran and marigold flower by Penicillium notatum NCIM 923. Biomed. Res. Int. 2013, 2013, 596380. [CrossRef]

10. Mahmoud, A.E.; Fathy, S.A.; Rashad, M.M.; Ezz, M.K.; Mohammed, A.T. Purification and characterization of a novel tannase produced by Kluyveromyces marxianus using olive pomace as solid support, and its promising role in gallic acid production. Int. J. Biol. Macromol. 2018, 107, 2342-2350. [CrossRef]

11. Chávez-González, M.; Rodríguez-Durán, L.V.; Balagurusamy, N.; Prado-Barragán, A.; Rodríguez, R.; Contreras, J.C.; Aguilar, C.N. Biotechnological Advances and Challenges of Tannase: An Overview. Food Bioprocess Technol. 2011, 5, 445-459. [CrossRef]

12. Zhang, Y.-N.; Yin, J.-F.; Chen, J.-X.; Wang, F.; Du, Q.-Z.; Jiang, Y.-W.; Xu, Y.-Q. Improving the sweet aftertaste of green tea infusion with tannase. Food Chem. 2016, 192, 470-476. [CrossRef]

13. Shao, Y.; Zhang, Y.-H.; Zhang, F.; Yang, Q.-M.; Weng, H.-F.; Xiao, Q.; Xiao, A.-F. Thermostable Tannase from Aspergillus Niger and Its Application in the Enzymatic Extraction of Green Tea. Molecules 2020, 25, 952. [CrossRef] [PubMed]

14. García-Conesa, M.-T.; Østergaard, P.; Kauppinen, S.; Williamson, G. Hydrolysis of diethyl diferulates by a tannase from Aspergillus oryzae. Carbohydr. Polym. 2001, 44, 319-324. [CrossRef]

15. Selwal, M.K.; Yadav, A.; Selwal, K.K.; Aggarwal, N.; Gupta, R.; Gautam, S.K. Tannase Production by Penicillium Atramentosum KM under SSF and its Applications in Wine Clarification and Tea Cream Solubilization. Braz. J. Microbiol. 2011, 42, 374-387. [CrossRef]

16. Sheldon, R.A. Enzyme Immobilization: The Quest for Optimum Performance. Adv. Synth. Catal. 2007, 349, 1289-1307. [CrossRef]

17. Silva, D.L.J.; Paola, C.M.; Alberto, C.A.; Fernandes, D.S.M.; Patrizia, P.; Bezerra, D.C.L.; Attilio, C. Immobilization of Aspergillus ficuum tannase in calcium alginate beads and its application in the treatment of boldo (Peumus boldus) tea. Int. J. Biol. Macromol. 2018, 118, 1989-1994.

18. Arana-Peña, S.; Carballares, D.; Morellon-Sterlling, R.; Berenguer-Murcia, Á.; Alcántara, A.R.; Rodrigues, R.C.; FernandezLafuente, R. Enzyme co-immobilization: Always the biocatalyst designers' choice ... or not? Biotechnol. Adv. 2020, 107584. [CrossRef] [PubMed]

19. Sheldon, R.A.; van Pelt, S. Enzyme immobilisation in biocatalysis: Why, what and how. Chem. Soc. Rev. 2013, $42,6223-6235$. [CrossRef]

20. Hernandez, K.; Fernandez-Lafuente, R. Control of protein immobilization: Coupling immobilization and site-directed mutagenesis to improve biocatalyst or biosensor performance. Enzym. Microb. Technol. 2011, 48, 107-122. [CrossRef] [PubMed]

21. Zhang, Y.H.; Chen, K.N.; Zhang, J.N.; Hong, R.; Zhang, X.Y.; Huang, J.H.; Wang, S.Z.; Fang, B.S. Preparation and evaluation of a polymer-metal-enzyme hybrid nanowire forthe immobilization of multiple oxidoreductases. J. Chem. Technol. Biotechnol. 2019, 94, 795-803. [CrossRef]

22. Wu, C.; Xu, C.; Ni, H.; Yang, Q.; Cai, H.; Xiao, A. Preparation and characterization of tannase immobilized onto carboxylfunctionalized superparamagnetic ferroferric oxide nanoparticles. Bioresour. Technol. 2016, 205, 67-74. [CrossRef]

23. Jana, A.; Halder, S.K.; Ghosh, K.; Paul, T.; Vágvölgyi, C.; Mondal, K.C.; Das Mohapatra, P.K. Tannase Immobilization by Chitin-Alginate Based Adsorption-Entrapment Technique and Its Exploitation in Fruit Juice Clarification. Food Bioprocess Technol. 2015, 8, 2319-2329. [CrossRef]

24. Klein, M.P.; Hackenhaar, C.R.; Lorenzoni, A.S.G.; Rodrigues, R.C.; Costa, T.M.H.; Ninow, J.L.; Hertz, P.F. Chitosan crosslinked with genipin as support matrix for application in food process: Support characterization and beta-D-galactosidase immobilization. Carbohydr. Polym. 2016, 137, 184-190. [CrossRef] [PubMed]

25. Melo, M.N.; Pereira, F.M.; Rocha, M.A.; Ribeiro, J.G.; Diz, F.M.; Monteiro, W.F.; Ligabue, R.A.; Severino, P.; Fricks, A.T. Immobilization and characterization of Horseradish Peroxidase into Chitosan and Chitosan/PEG nanoparticles: A comparative study. Process. Biochem. 2020, 98, 160-171. [CrossRef]

26. Flores, E.E.E.; Cardoso, F.D.; Siqueira, L.B.; Ricardi, N.C.; Costa, T.H.; Rodrigues, R.C.; Klein, M.P.; Hertz, P.F. Influence of reaction parameters in the polymerization between genipin and chitosan for enzyme immobilization. Process. Biochem. 2019, 84, 73-80. [CrossRef]

27. Tharanathan, R.N.; Kittur, F.S. Chitin-The Undisputed Biomolecule of Great Potential. Crit. Rev. Food Sci. Nutr. 2003, 43, 61-87. [CrossRef] [PubMed]

28. Kurita, K. Controlled functionalization of the polysaccharide chitin. Prog. Polym. Sci. 2001, 26, 1921-1971. [CrossRef]

29. Krajewska, B. Application of chitin- and chitosan-based materials for enzyme immobilizations: A review. Enzym. Microb. Technol. 2004, 35, 126-139. [CrossRef]

30. Gan, Q.; Wang, T. Chitosan nanoparticle as protein delivery carrier-Systematic examination of fabrication conditions for efficient loading and release. Colloids Surf. B Biointerfaces 2007, 59, 24-34. [CrossRef]

31. Jing, Z.-W.; Ma, Z.-W.; Li, C.; Jia, Y.-Y.; Luo, M.; Ma, X.-X.; Zhou, S.-Y.; Zhang, B.-L. Chitosan cross-linked with poly(ethylene glycol)dialdehyde via reductive amination as effective controlled release carriers for oral protein drug delivery. Bioorganic Med. Chem. Lett. 2017, 27, 1003-1006. [CrossRef] 
32. Bor, G.; Mytych, J.; Zebrowski, J.; Wnuk, M.; Şanl1-Mohamed, G. Cytotoxic and cytostatic side effects of chitosan nanoparticles as a non-viral gene carrier. Int. J. Pharm. 2016, 513, 431-437. [CrossRef] [PubMed]

33. Srivastava, B.; Singh, H.; Khatri, M.; Singh, G.; Arya, S.K. Immobilization of keratinase on chitosan grafted-beta-cyclodextrin for the improvement of the enzyme properties and application of free keratinase in the textile industry. Int. J. Biol. Macromol. 2020, 165, 1099-1110. [CrossRef]

34. Baidamshina, D.R.; Koroleva, V.A.; Trizna, E.Y.; Pankova, S.M.; Agafonova, M.N.; Chirkova, M.N.; Vasileva, O.S.; Akhmetov, N.; Shubina, V.V.; Porfiryev, A.G.; et al. Anti-biofilm and wound-healing activity of chitosan-immobilized Ficin. Int. J. Biol. Macromol. 2020, 164, 4205-4217. [CrossRef]

35. Yang, J.; Xu, P.; Long, L.; Ding, S. Production of lactobionic acid using an immobilized cellobiose dehydrogenase/laccase system on magnetic chitosan spheres. Process. Biochem. 2021, 100, 1-9. [CrossRef]

36. Bilal, M.; Iqbal, H.M. Naturally-derived biopolymers: Potential platforms for enzyme immobilization. Int. J. Biol. Macromol. 2019, 130, 462-482. [CrossRef]

37. Chatterjee, S.; Lee, M.W.; Woo, S.H. Enhanced mechanical strength of chitosan hydrogel beads by impregnation with carbon nanotubes. Carbon 2009, 47, 2933-2936. [CrossRef]

38. Wahba, M.I. Porous chitosan beads of superior mechanical properties for the covalent immobilization of enzymes. Int. J. Biol. Macromol. 2017, 105, 894-904. [CrossRef] [PubMed]

39. Pereira, S.P.; Oliveira, R.; Coelho, S.; Musso, C.; Soares, A.M.; Domingues, I.; Nogueira, A.J. From sub cellular to community level: Toxicity of glutaraldehyde to several aquatic organisms. Sci. Total. Environ. 2014, 470-471, 147-158. [CrossRef]

40. Djerassi, C.; Nakano, T.; James, A.N.; Zalkow, L.H.; Shoolery, J.N. Terpenoids. XLVII. The structure of genipin. J. Org. Chem. 1961, 26, 1192-1206. [CrossRef]

41. Tacias-Pascacio, V.G.; García-Parra, E.; Vela-Gutiérrez, G.; Virgen-Ortiz, J.J.; Berenguer-Murcia, Á.; Alcántara, A.R.; FernandezLafuente, R. Genipin as An Emergent Tool in the Design of Biocatalysts: Mechanism of Reaction and Applications. Catalysts 2019, 19, 1035. [CrossRef]

42. Sung, H.-W.; Huang, R.-N.; Huang, L.L.; Tsai, C.-C. In vitro evaluation of cytotoxicity of a naturally occurring cross-linking reagent for biological tissue fixation. J. Biomater. Sci. Polym. Ed. 1999, 10, 63-78. [CrossRef] [PubMed]

43. Cavello, I.A.; Contreras-Esquivel, J.C.; Cavalitto, S.F. Immobilization of a keratinolytic protease from Purpureocillium lilacinum on genipin activated-chitosan beads. Process. Biochem. 2014, 49, 1332-1336. [CrossRef]

44. Khan, N.; Maseet, M.; Basir, S.F. Synthesis and characterization of biodiesel from waste cooking oil by lipase immobilized on genipin cross-linked chitosan beads: A green approach. Int. J. Green Energy 2019, 17, 84-93. [CrossRef]

45. Boudrant, J.; Woodley, J.M.; Fernandez-Lafuente, R. Parameters necessary to define an immobilized enzyme preparation. Process. Biochem. 2020, 90, 66-80. [CrossRef]

46. Alamsyah, G.; Albels, V.A.; Sahlan, M.; Hermansyah, H. Effect of chitosan's amino group in adsorption-crosslinking immobilization of lipase enzyme on resin to catalyze biodiesel synthesis. Energy Procedia 2017, 136, 47-52. [CrossRef]

47. Olshansky, Y.; Masaphy, S.; Root, R.A.; Rytwo, G. Immobilization of Rhus vernicifera laccase on sepiolite; effect of chitosan and copper modification on laccase adsorption and activity. Appl. Clay Sci. 2018, 152, 143-147. [CrossRef]

48. Ma, X.; Qiao, C.; Zhang, J.; Xu, J. Effect of sorbitol content on microstructure and thermal properties of chitosan films. Int. J. Biol. Macromol. 2018, 119, 1294-1297. [CrossRef] [PubMed]

49. Muzzarelli, R.A. Genipin-crosslinked chitosan hydrogels as biomedical and pharmaceutical aids. Carbohydr. Polym. 2009, 77, 1-9. [CrossRef]

50. Muzzarelli, R.A.A.; El Mehtedi, M.; Bottegoni, C.; Aquili, A.; Gigante, A. Genipin-Crosslinked Chitosan Gels and Scaffolds for Tissue Engineering and Regeneration of Cartilage and Bone. Mar. Drugs 2015, 13, 7314-7338. [CrossRef]

51. Muzzarelli, R.A.; El Mehtedi, M.; Bottegoni, C.; Gigante, A. Physical properties imparted by genipin to chitosan for tissue regeneration with human stem cells: A review. Int. J. Biol. Macromol. 2016, 93, 1366-1381. [CrossRef]

52. Delmar, K.; Bianco-Peled, H. The dramatic effect of small $\mathrm{pH}$ changes on the properties of chitosan hydrogels crosslinked with genipin. Carbohydr. Polym. 2015, 127, 28-37. [CrossRef] [PubMed]

53. Yu, S.-H.; Wu, S.-J.; Wu, J.-Y.; Wen, D.-Y.; Mi, F.-L. Preparation of fucoidan-shelled and genipin-crosslinked chitosan beads for antibacterial application. Carbohydr. Polym. 2015, 126, 97-107. [CrossRef]

54. Sathishkumar, P.; Kamala-Kannan, S.; Cho, M.; Kim, J.S.; Hadibarata, T.; Salim, M.R.; Oh, B.-T. Laccase immobilization on cellulose nanofiber: The catalytic efficiency and recyclic application for simulated dye effluent treatment. J. Mol. Catal. B Enzym. 2014, 100, 111-120. [CrossRef]

55. Monier, M.; Ayad, D.; Wei, Y.; Sarhan, A. Preparation and characterization of magnetic chelating resin based on chitosan for adsorption of $\mathrm{Cu}(\mathrm{II}), \mathrm{Co}(\mathrm{II})$, and $\mathrm{Ni}(\mathrm{II})$ ions. React. Funct. Polym. 2010, 70, 257-266. [CrossRef]

56. Lambert, J.B. Introduction to Organic Spectroscopy. In Introduction to Organic Spectroscopy; Lambert, J.B., Shurvell, H.F., Lightner, D.A., Cooks, R.G., Eds.; Macmillan Publishing Company: New York, NY, USA, 1987.

57. Gámiz-González, M.; Correia, D.; Lanceros-Mendez, S.; Sencadas, V.; Ribelles, J.G.; Vidaurre, A. Kinetic study of thermal degradation of chitosan as a function of deacetylation degree. Carbohydr. Polym. 2017, 167, 52-58. [CrossRef]

58. Zohuriaan, M.; Shokrolahi, F. Thermal studies on natural and modified gums. Polym. Test. 2004, 23, 575-579. [CrossRef]

59. Peniche-Covas, C.; Argüelles-Monal, W.; Román, J.S. A kinetic study of the thermal degradation of chitosan and a mercaptan derivative of chitosan. Polym. Degrad. Stab. 1993, 39, 21-28. [CrossRef] 
60. Xiao, Q.; Liu, C.; Ni, H.; Zhu, Y.; Jiang, Z.; Xiao, A. $\beta$-Agarase immobilized on tannic acid-modified Fe3O4 nanoparticles for efficient preparation of bioactive neoagaro-oligosaccharide. Food Chem. 2019, 272, 586-595. [CrossRef]

61. Wang, B.; Cheng, F.; Lu, Y.; Ge, W.; Zhang, M.; Yue, B. Immobilization of pectinase from Penicillium oxalicum F67 onto magnetic cornstarch microspheres: Characterization and application in juice production. J. Mol. Catal. B Enzym. 2013, 97, 137-143. [CrossRef]

62. Ji, Q.; Wang, B.; Tan, J.; Zhu, L.; Li, L. Immobilized multienzymatic systems for catalysis of cascade reactions. Process. Biochem. 2016, 51, 1193-1203. [CrossRef]

63. Atacan, K.; Özacar, M. Characterization and immobilization of trypsin on tannic acid modified Fe3O4 nanoparticles. Colloid Surf. B Biointerfaces 2015, 128, 227-236. [CrossRef] [PubMed]

64. Li, R.; Fu, G.; Liu, C.; McClements, D.J.; Wan, Y.; Wang, S.; Liu, T. Tannase immobilisation by amino-functionalised magnetic Fe3O4-chitosan nanoparticles and its application in tea infusion. Int. J. Biol. Macromol. 2018, 114, 1134-1143. [CrossRef] [PubMed]

65. Rodrigues, R.C.; Ortiz, C.; Berenguer-Murcia, Á.; Torres, R.; Fernández-Lafuente, R. Modifying enzyme activity and selectivity by immobilization. Chem. Soc. Rev. 2013, 42, 6290-6307. [CrossRef] [PubMed]

66. Venezia, V.; Sannino, F.; Costantini, A.; Silvestri, B.; Cimino, S.; Califano, V. Mesoporous silica nanoparticles for $\beta$-glucosidase immobilization by templating with a green material: Tannic acid. Microporous Mesoporous Mater. 2020, 302, 110203. [CrossRef]

67. Sannino, F.; Costantini, A.; Ruffo, F.; Aronne, A.; Venezia, V.; Califano, V. Covalent Immobilization of $\beta$-Glucosidase into Mesoporous Silica Nanoparticles from Anhydrous Acetone Enhances Its Catalytic Performance. Nanomaterials 2020, $10,108$. [CrossRef]

68. Figueira, J.A.; Sato, H.H.; Fernandes, P. Establishing the Feasibility of Using $\beta$-Glucosidase Entrapped in Lentikats and in Sol-Gel Supports for Cellobiose Hydrolysis. J. Agric. Food Chem. 2013, 61, 626-634. [CrossRef]

69. Verma, M.L.; Rajkhowa, R.; Wang, X.; Barrow, C.J.; Puri, M. Exploring novel ultrafine Eri silk bioscaffold for enzyme stabilisation in cellobiose hydrolysis. Bioresour. Technol. 2013, 145, 302-306. [CrossRef]

70. Bursal, E.; Koeksal, E. Evaluation of reducing power and radical scavenging activities of water and ethanol extracts from sumac (Rhus coriaria L.). Food Res. Int. 2011, 44, 2217-2221. [CrossRef]

71. Ranilla, L.G.; Kwon, Y.-I.; Apostolidis, E.; Shetty, K. Phenolic compounds, antioxidant activity and in vitro inhibitory potential against key enzymes relevant for hyperglycemia and hypertension of commonly used medicinal plants, herbs and spices in Latin America. Bioresour. Technol. 2010, 101, 4676-4689. [CrossRef]

72. Castiglioni, S.; Damiani, E.; Astolfi, P.; Carloni, P. Influence of steeping conditions (time, temperature, and particle size) on antioxidant properties and sensory attributes of some white and green teas. Int. J. Food Sci. Nutr. 2015, 66, 491-497. [CrossRef] [PubMed]

73. Dorman, H.; Peltoketo, A.; Hiltunen, R.; Tikkanen, M. Characterisation of the antioxidant properties of de-odourised aqueous extracts from selected Lamiaceae herbs. Food Chem. 2003, 83, 255-262. [CrossRef]

74. Kataki, M.S.; Kakoti, B.B.; Bhuyan, B.; Rajkumari, A.; Rajak, P. Garden rue inhibits the arachidonic acid pathway, scavenges free radicals, and elevates FRAP: Role in inflammation. Chin. J. Nat. Med. 2014, 12, 172-179. [CrossRef]

75. Lu, M.-J.; Chen, C. Enzymatic modification by tannase increases the antioxidant activity of green tea. Food Res. Int. 2008, 41, 130-137. [CrossRef]

76. Macedo, J.; Battestin, V.; Ribeiro, M. Increasing the antioxidant power of tea extracts by biotransformation of polyphenols. Food Chem. 2011, 126, 491-497. [CrossRef]

77. Almajano, M.P.; Carbó, R.; Jiménez, J.A.L.; Gordon, M.H. Antioxidant and antimicrobial activities of tea infusions. Food Chem. 2008, 108, 55-63. [CrossRef]

78. Miao, M.; Jiang, H.; Jiang, B.; Li, Y.; Cui, S.W.; Jin, Z. Elucidation of structural difference in theaflavins for modulation of starch digestion. J. Funct. Foods 2013, 5, 2024-2029. [CrossRef]

79. Miao, M.; Jiang, H.; Jiang, B.; Li, Y.; Cui, S.W.; Zhang, T. Structure elucidation of catechins for modulation of starch digestion. LWT 2014, 57, 188-193. [CrossRef]

80. Yang, X.; Kong, F. Effects of tea polyphenols and different teas on pancreatic $\alpha$-amylase activity in vitro. LWT 2016, 66, 232-238. [CrossRef]

81. Qu, F.; Zeng, W.; Tong, X.; Feng, W.; Chen, Y.; Ni, D. The new insight into the influence of fermentation temperature on quality and bioactivities of black tea. LWT 2020, 117, 108646. [CrossRef]

82. Matsui, T.; Tanaka, T.; Tamura, S.; Toshima, A.; Tamaya, K. $\alpha$-Glucosidase Inhibitory Profile of Catechins and Theaflavins. J. Agric. Food. Chem. 2007, 55, 99-105. [CrossRef]

83. Kwon, Y.-I.; A Vattem, D.; Shetty, K. Evaluation of clonal herbs of Lamiaceae species for management of diabetes and hypertension. Asia Pac. J. Clin. Nutr. 2006, 15, 107-118.

84. Tadera, K.; Minami, Y.; Takamatsu, K.; Matsuoka, T. Inhibition of $\alpha$-Glucosidase and $\alpha$-Amylase by Flavonoids. J. Nutr. Sci. Vitaminol. 2006, 52, 149-153. [CrossRef] [PubMed]

85. Sharma, S.; Bhat, T.; Dawra, R. A Spectrophotometric Method for Assay of Tannase Using Rhodanine. Anal. Biochem. 2000, 279, 85-89. [CrossRef] [PubMed]

86. Shuyuan, L.; Zeyi, A.; Fengfeng, Q.; Yuqiong, C.; Dejiang, N. Effect of steeping temperature on antioxidant and inhibitory activities of green tea extracts against $\alpha$-amylase, $\alpha$-glucosidase and intestinal glucose uptake. Food Chem. 2017, 234, 168-173. 